\title{
A felelösségteljes innováció és a gazdasági racionalitás kapcsolatrendszere vállalati környezetben
}

\begin{abstract}
A felelősségteljes innováció elméletének vállalati folyamatokba integrálása és ezen keresztuil a társadalom életminőségének javítása fontos kihívást jelent a téma multidiszciplináris kutatóközössége számára. Az eddig alkalmazott módszerek jórészt etikai és nem közgazdaságtani oldalról közelítették a beavatkozásokat, így inkább akadémiai környezetben értek el sikereket. Ezzel szemben a profitmaximalizálásra törekvő innovatív vállalatok közgazdasági megfontolások alapján hozzák meg innovációs döntéseiket. Ezért előfordulhat, hogy az innovatív vállalatok profitmaximalizálási célja szemben áll a társadalom életminőség-maximalizáló céljával, és a racionális vállalatok nem a felelősségteljes innovációs modellt választják. Jelen tanulmány célja az, hogy egy eddig nem kutatott nézőpontból vizsgálja meg a felelősségteljes innováció széles körü vállalati bevezetésének lehetőségét. A felelösségteljes innovációs döntések következményeit nem etikai szempontból, hanem a felelősségteljes innováció költségeinek és hasznainak oldaláról közelítjük meg, és egy minősítő jelző alkalmazását javasoljuk. Megmutatjuk a felelősségteljes innovációs modell racionális választássá tételének fontosságát és lehetőségét, $s$ új kutatási és diszkussziós lehetőségeket kínálunk a felelősségteljes innováció nemzetközi szakirodalmának közgazdasági kiterjesztésére.* Journal of Economic Literature (JEL) kód: 031, 032, 035, D62, D82.
\end{abstract}

Napjaink egyik kiemelt érdeklődéssel övezett témaköre a felelősségteljes innováció, ${ }^{1}$ amely a kutatás-fejlesztési és innovációs eredményekhez köthető nem szándékolt negatív hatások csökkentését és ezen keresztül a társadalom életminőségének javítását szolgálja (Grinbaum-Groves [2013], Owen és szerzőtársai [2013], Burget és szerzőtársai

* Jelen tanulmány megjelenését az EFOP-3.6.2-16-2017-00007 azonosítószámú, EU-s társfinanszírozású projekt támogatta. A szerzők köszönetet mondanak Nádas Nikolettának a kutatási háttérmunkáért.

${ }^{1}$ A felelösségteljes kutatás és innováció (Responsible Research and Innovation, RRI) vállalati alkalmazásban általában felelősségteljes innovációként (Responsible Innovation, $R I$ ) szerepel a szakirodalomban.

Lukovics Miklós közgazdász, egyetemi docens, Szegedi Tudományegyetem Gazdaságtudományi Kar (e-mail:miki@eco.u-szeged.hu).

Nagy Benedek közgazdász, egyetemi adjunktus, Szegedi Tudományegyetem Gazdaságtudományi Kar (e-mail: nagy.benedek@eco.u-szeged.hu).

A kézirat első változata 2020. május 26-án érkezett szerkesztőségünkbe.

DOI: http://dx.doi.org/10.18414/KSZ.2021.4.421 
[2017]). A kutatókat és a gyakorlati szakembereket egyaránt érintő, kiemelt jelentőségü kihívás az, hogy a felelősségteljes innováció elméletét a napi innovációs folyamatokba is át lehessen ültetni. Erre az elmúlt években ígéretes etikai megközelítésű módszerek születtek - például az arizonai egyetemen a társadalmi-technikai integrációs STIRkutatásé vagy a bécsi egyetemen kidolgozott Imagine RRI módszer (Felt és szerzőtársai [2018]). Közös ismérvük, hogy a kutató-fejlesztők egyéni motivációira hatnak, és egy viszonylag hosszú tanulási folyamat során fejtik ki hatásukat (Fisher-Rip [2013], Fisher-Mahajan [2006], Eden és szerzőtársai [2013]).

Értékes előzetes eredmények mutathatók fel egyéni szintű alkalmazások területén: a felelösségteljes innováció elmélete beépíthető a napi szintü $\mathrm{K}+\mathrm{F}+\mathrm{I}$ munkába (Bergvall-Kareborn és szerzőtársai [2009], Schuurman és szerzötársai [2011], PavieCarthy [2015], Fisher-Schuurbiers [2013], Fisher-Maricle [2015]), azonban ezen eredmények elsősorban akadémiai környezetben születtek, vállalati innovációs környezetben komoly nehézségek tárhatók fel (Yaghmaei [2018], Lukovics és szerzötársai [2016], [2019]). A vállalatok a felelösségteljes innováció bevezetésétől is egyértelmü gazdasági előnyt várnak: a Ko-Kim [2020] száz technológiai céget vizsgáló felmérésében szereplő célok közül a gazdasági eredményesség relatív súlya volt a legerősebb $(0,502)$, a melyet a technológiai javulás $(0,341)$ követett. Figyelemre méltó, hogy a profiton túli társadalmi jóléti hozzájárulás csak 0,157-es súlyt kapott, ezen belül a társadalmi hozzájárulás relatív súlya 0,092, az etikai altényező relatív súlya csupán 0,065. Ez az eredmény szintén felveti annak szükségességét, hogy a vállalatok esetében az etikai jellegü módszerek helyett közgazdasági logikát kell alkalmazni.

Ennek oka, hogy a felelősségteljes innováció alkalmazása (ezen keresztül a társadalom életminőség-maximalizáló célja) az innovatív vállalatok profitmaximalizálási céljaival ellentétes lehet. A felelösségteljes innováció alkalmazása ugyanis megnöveli az innovációs költségeket: újabb tesztek, társadalmi-környezeti hatásvizsgálatok, hosszabb fejlesztési időszakok stb. lehetnek szükségesek a nem szándékolt negatív mellékhatások csökkentéséhez. E költségek ellentételezése a piacon keresztül azonban egyelöre nehézkes.

A piacra bevezetett vállalati innovációk előre nem látott jövőbeli többletköltséget vagy akár többlethasznot is eredményezhetnek, de ezek nem a vállalatnál merülnek fel, így ők ezt a tényt figyelmen kívül hagyják. Ez társadalmi szempontból nem hatékony, de a vállalat számára üzleti szempontból racionális, hiszen ezeknek a várható jövőbeli károknak nagy része nem a vállalatnak okoz többletköltséget, és a többlethasznok sem a vállalatnál realizálódnak. Így előfordulhat, hogy az innovatív vállalatok profitmaximalizálási célja szemben áll a társadalom életminőség-maximalizáló céljával, és a racionális vállalatok nem a felelősségteljes innovációs modellt választják.

A fentiekből adódóan kutatásunkban arra a kérdésre keressük a választ, hogy miként érhetö el az, hogy a felelősségteljes innovációs modellt a vállalatok ne csak a kutató-fejlesztők esetleges morális érzékenysége alapján válasszák, hanem az egyszersmind a profitmaximalizálási céljukkal is egybeessen.

A kutatási kérdés megválaszolásához magát a felelősségteljes innováció fogalmát is az eddigiektől eltérő megvilágításba kell helyezzük. A felelősségteljes innováció nemzetközileg elismert fogalmi megközelítései ugyanis explicit módon nem veszik 
figyelembe azt, hogy az innovátor vállalat számára milyen bevétel- és költségvonzatai vannak a felelösségteljes innovációs döntéseknek.

Úgy véljük, hogy a felelősségteljes innovációs modell széles körű vállalati alkalmazásának feltétele, hogy a társadalom életminőség-maximalizáló célja ne legyen ellentétes a vállalatok profitmaximalizálási céljával. Ennek elérése érdekében egy olyan módszert keresünk, amellyel a vállalat költségeit és bevételeit piaci alapon úgy lehetne befolyásolni, hogy a felelősségteljes innováció által generált külső hatások belsővé tehetők legyenek. Ez a megközelítés megteremti a lehetöségét annak, hogy az önérdekkövető innovatív vállalatok kritikus tömege a felelősségteljes innováció gondolatköre szerint végezze $\mathrm{K}+\mathrm{F}+\mathrm{I}$-tevékenységét. Így várhatóan lényegesen több vállalat állítható a felelősségteljes innováció oldalára, mint ha az eddig alkalmazott módszerek szerint a kutató-fejlesztők morális érzékenységére bíznánk a választást.

Ily módon a közgazdaság-tudomány egy olyan gondolatmenettel támogathatja a nemzetközi felelősségteljes innovációval foglalkozó kutatóközösséget, amelynek - bár a közgazdászok számára nem új - újdonságtartalma ebben a témában jelentős. Megközelítésünk a közgazdászok számára új kutatási és diszkussziós lehetőségeket nyit meg a felelősségteljes innováció nemzetközi szakirodalmának közgazdasági kiterjesztésére.

\section{Etikai módszerek a felelősségteljes innováció előmozdításáért}

A technológiai fejlődés várható hatásaira és az ehhez kapcsolódó gazdasági etikára vonatkozó szakirodalmi megközelítések rendkívül széles körűek, és sok esetben ellentétes álláspontot képviselnek. Bár a közgazdaságtan tudománya a morálfilozófia egyik ágaként kezdte klasszikus pályafutását, ahogy a modellek és a matematizálás elötérbe kerültek, és teret nyert a homo oeconomicus felfogásmód, úgy szorultak ki teljesen belőle az etikai megfontolások (Blommestein [2006], Hausman és szerzőtársai [2016], Kargol-Wasiluk és szerzőtársai [2018]). Számos neves közgazdász tett azonban kísérletet arra, hogy a moralitást visszahozza a közgazdasági modellekbe, és a homo oeconomicus helyett a homo moralis legyen a kiindulópont (Harsanyi [1977], Sen [1993], Davis [2018]).

Ezen - egymásnak sokszor ellentmondó - megközelítések is rávilágítanak a téma komplexitására. Abban azonban talán egyetértenek, hogy az innovációhoz olykor olyan elöre nem látható kockázatok és bizonytalanság is párosulhat, amely hosszú távon negatív hatású lehet (Buzás-Lukovics [2015]).

Az innovációs eredmények esetleges jövőbeli negatív hatásait próbálja csökkenteni a jelenben a felelősségteljes innováció. A fogalom széleskörủen értelmezhető, így másmás megközelítések születtek meghatározására (Owen és szerzötársai [2012], Sutcliffe [2013], Buzás-Lukovics [2015]). Ezek közül Schomberg meghatározása a legszélesebb körben elfogadott:

„[A felelősségteljes innováció egy] transzparens és interaktív folyamat, amelyben a társadalmi szereplők és az innovátorok kölcsönös felelősséget vállalnak az innovációs folyamat 
és eredményei etikai elfogadhatósága, fenntarthatósága és társadalmi kívánatossága iránt (annak érdekében, hogy a tudományos és technológiai fejlődés beépülhessen a társadalomba)." (Schomberg [2013] 60. o.)

Ennek értelmében az innováció akkor lehet felelősségteljes, ha az innovációs folyamat során figyelembe vesszük a társadalmi, környezeti és etikai szempontokat is, vagyis ha az innováció társadalmi igényeken alapszik, és az érintettek minél szélesebb körét bevonják az innovációs folyamatba (Forsberg és szerzőtársai [2015]). Ez a megközelítés kiemelt figyelmet fordít arra, hogy az esetlegesen felmerülö környezeti, társadalmi és etikai kockázatok ellen preventív intézkedéseket lehessen tenni.

Amennyiben a jelenleg alkalmazott etikai megközelítés müködési mechanizmusát szeretnénk megérteni, érdemes az arizonai egyetem társadalmi-technikai integrációs kutatásának (Socio-Technical Integration Research, STIR) módszerére koncentrálnunk (Owen és szerzőtársai [2012], Fisher és szerzőtársai [2006], Stilgoe és szerzőtársai [2013]). A STIR ugyanis a jelenleg alkalmazott módszerek közül a leghoszszabb (több mint egy évtizedes) múlttal rendelkezik, és egyúttal a legrészletesebben dokumentált (Lukovics és szerzőtársai [2016], Stilgoe és szerzőtársai [2013]). A világ 21 országában ${ }^{2}$ sikeresen alkalmazták már (Flipse és szerzőtársai [2013], Schuurbiers [2011], Stilgoe és szerzőtársai [2013], Schomberg [2012]), így kiválóan alkalmas az etikai megközelítés megértésére.

A STIR egy olyan mechanizmus, amely a műszaki-természettudományi innovációs folyamatokba társadalomtudományi szempontokat épít be (Owen és szerzőtársai [2012], Fisher és szerzőtársai [2006], Stilgoe és szerzőtársai [2013]). A STIR során egy társadalomtudós 12 hétre integrálódik egy müszaki-természettudományi kutatócsoport munkájába, és ennek során konkrét munkafolyamatokhoz illeszkedő interakciót folytat - egyszerre csak egy személlyel (Fisher és szerzőtársai [2006], Flipse és szerzötársai [2013], [2014], Schuurbiers [2011]). Ennek célja a kutató-fejlesztők keretfüggőségének csökkentése, látókörük kiterjesztése és döntéseikbe a korábban figyelembe nem vett szempontok integrálása (Schuurbiers [2011]). A STIR előnye, hogy rendkívül alapos, ezáltal fenntartható és tartós elköteleződést alakít ki a kutató-fejlesztőben. Hátránya, hogy hosszú időt vesz igénybe (12 hét), amely során a kutatásba egyszerre csupán 2-4 természettudományi kutatót vonnak be. Emiatt e módszertan segítségével csak nagyon lassan terjedhet a felelősségteljes innováció alkalmazása.

E módszert többségében akadémiai környezetben alkalmazták sikeresen, azonban vállalati alkalmazás esetén további hátrányokat derítettek fel a kutatók: a megkeresett üzleti innovációs szereplők döntő többsége elzárkózott a módszer alkalmazása elöl azzal az indokkal, hogy nem látta rövid távú megtérülését (Nádas és szerzötársai [2017], Lukovics és szerzőtársai [2016], [2017], [2019]).

A felelősségteljes innovációs gyakorlat elterjesztésére számos további, szintén etikai módszer áll rendelkezésre, például az Imagine RRI módszer (Felt és szerzőtársai

\footnotetext{
${ }^{2}$ Belgium, Bosznia-Hercegovina, Csehország, Dánia, Dél-Korea, Egyesült Államok, Egyesült Királyság, Észak-Îrország, Franciaország, Hollandia, Horvátország, Japán, Kanada, Kína, Magyarország, Németország, Románia, Spanyolország, Svájc, Szlovákia, Szlovénia.
} 
[2018], Pavie és szerzőtársai [2014], Porcari és szerzőtársai [2016], Fisher-Schuurbiers [2013], Fisher-Maricle [2015] stb.). Ezek a módszerek a STIR-hez hasonlóan személyes interakciókon alapulnak, a kutató-fejlesztők egyéni motivációján keresztül kívánják a felelös gondolkodást erősíteni, így lassú terjedésüek. Emiatt az etikai módszerek elsősorban akadémiai kutatási környezetben alkalmazhatóak, üzleti környezetben kevésbé. Amennyiben célunk a felelősségteljes innováció vállalati alkalmazásának elősegítése, akkor célszerü a jelenlegitől eltérő módszerekben gondolkodni.

\section{A felelősségteljes innováció neoklasszikus megközelítése}

Ahhoz, hogy a felelősségteljes innováció gyakorlati alkalmazásának későbbiekben bemutatandó alternatív megközelítését megértsük, fontos, hogy magát a fogalmat is az eddigiektől eltérő megvilágításba helyezzük. A nemzetközileg elismert fogalmi megközelítések ugyanis explicit módon nem veszik figyelembe azt, hogy a felelősségteljes innovációs döntéseknek a vállalat számára milyen bevétel- és költségvonzatai vannak. Ezzel szemben mi éppen arra szeretnénk rámutatni, hogy hogyan ösztönözhetők a piaci alapon döntést hozó, profitmaximalizálásra törekvő vállalatok a felelősségteljes innovációs modell alkalmazására.

Nagyon fontosnak tartjuk, hogy gondolkodásunkat a felelösségteljes innováció nemzetközileg elismert fogalmaihoz kössük, így logikánkat a tanulmányunk elején bemutatott definícióból indítjuk. A felelösségteljes innováció fogalmának (Schomberg [2013]) „társadalmilag kívánatos” elemét a közgazdaságtani szóhasználatban a (Pareto-) Kaldor-Hicks-kritériummal operacionalizálhatjuk, vagyis ebben az esetben az innováció - minden érintett felet figyelembe véve - összességében több hasznot eredményez, mint amennyi költséget jelent. A felelős innovátoroknak olyan innovációkra kell törekedniük, amelyek megfelelnek ennek a követelménynek (Lukovics és szerzőtársai [2019]).

Az innovációs folyamat azonban inherens kockázatosságának és jövőbeli irányának köszönhetően külső felekre is hatással van (akik az innovátoroktól térben és időben nagyon messze is lehetnek). Ezek a nem szándékolt pozitív vagy negatív mellékhatások, amelyek az innovációból származnak, de nem jelennek meg költségként vagy bevételként az innovátoroknál, és ezért ők nem is veszik figyelembe ezeket. Ekkor azonban a társadalom szempontjából nem kívánatos, nem optimális módon viselkednek. Az innovátorok a profitmotívum alapján döntenek, és csak azokat a költségeket és hasznokat veszik figyelembe, amelyeket magukra nézve tartanak relevánsnak, figyelmen kívül hagyva mások költségeit és hasznait. Ebben az esetben olyan innovációt valósítanak meg, vagy olyan funkciókat hoznak létre, amelyeket az összes érintett (a társadalom egésze) szempontjait figyelembe véve nem lenne szabad, illetve éppenséggel nem valósítanak meg olyan innovációt, vagy nem hoznak létre olyan funkciókat, amelyeket társadalmi szempontból meg kellene valósítani (Lukovics és szerzőtársai [2019]). Ezek a külső, tovagyürüző hatások a felelősségteljes innováció központi problémái, amelyeket a téma kutatói azonosítottak és igyekeznek kezelni. 
Tanulmányunkban amellett érvelünk, hogy a felelösségteljes innovációs modell pozitív külső hatások forrása lehet. A közismert költség-haszon keretben is megjeleníthető a felelősségteljes innováció pozitív externáliákból adódó hatása (1. ábra).

\section{1. ábra}

A felelősségteljes innovációs modell által generált pozitív külső hatások
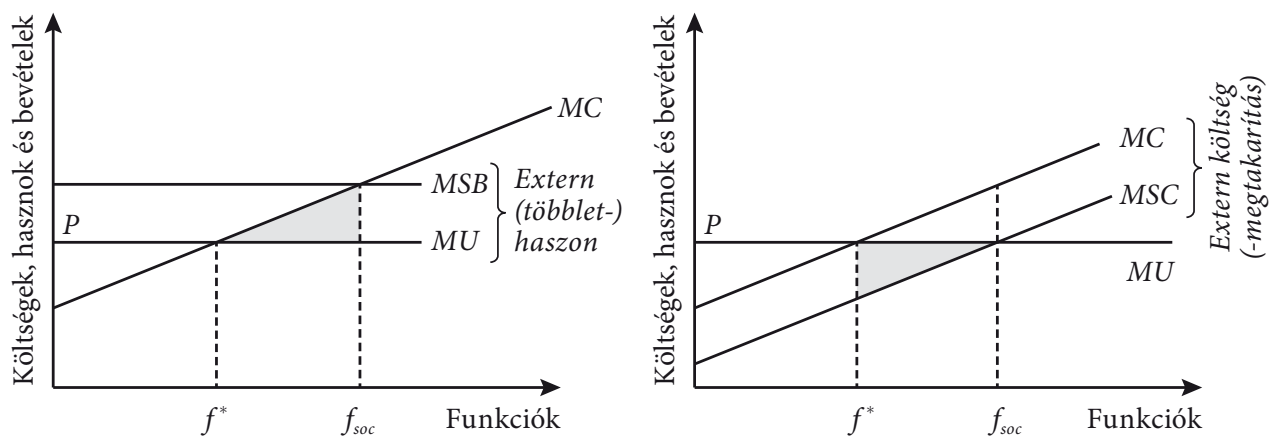

MSC: társadalmi határköltség, $M S B$ : társadalmi határhaszon, $M C$ : határköltség, $M U$ : határhaszon, $f^{*}$ profitmaximalizáló, $f_{s o c}$ a társadalom számára optimális szint, $P$ : ár.

Forrás: saját szerkesztés Pindyck-Rubinfeld [2009] alapján.

Az emelkedő határköltségfüggvény esetünkben azt mutatja, hogy az innovátor milyen költséggel tudja az innovatív terméket újabb funkciókkal ellátni, a vízszintes határhaszon pedig ezen funkcióknak az értéke, azaz a fogyasztók fizetési hajlandósága. Ez egy versenyzői piac által meghatározott érték, az innovátor számára exogén módon adott nagyság. Amennyiben a vállalat felelősségteljes módon végzi az innovációs tevékenységét, vagyis igyekszik felmérni, hogy innovációjából milyen későbbi káros mellékhatások származhatnak, akkor két dolog lehetséges (akár együttesen is):

- további hasznot generál a társadalom számára (például mert elöre gondolt a későbbi lehetséges biztonsági problémákra, ezt mutatja a bal oldali ábra),

- csökkenti a társadalomnak az ezen innovációval kapcsolatos összes költségét (mert például könnyebbé tette a terméke későbbi adaptációját, ezt mutatja a jobb oldali ábra).

Akármelyik legyen is a helyzet, a társadalom szempontjából kívánatos lenne további erőforrás-ráfordítás árán többletfunkciókkal bővíteni az innovációt egészen $f_{s o c}$-ig, és amennyiben a vállalat nem megy el addig, akkor ez a társadalom számára jóléti veszteséget okoz. Ez a jóléti veszteség az ábrán a bevonalkázott háromszög alakú terület, amely abból származik, hogy a vállalat nem fejleszt ki olyan funkciókat, amelyek a társadalom egésze szempontjából értékesebbek, mint amennyibe a kifejlesztésük kerül. A közgazdaságtan különböző internalizálási lehetőségeket kínál az externáliaproblémára, melyekkel a vállalat által választott optimum közelíthető a társadalmi optimumhoz. A szabadalmi védelem intézménye például egy jól ismert internalizációja annak az extern haszonnak, amit egy innovátor az utána jövő innovátorok számára nyújt azáltal, hogy megteremti az alapokat, amelyekre 
a későbbi fejlesztések épülhetnek (Scotchmer [1991]). Más területeken az externáliák internalizálásának bevált módja a támogatás (pozitív externália) vagy az adóztatás (negatív externália) (Pindyck-Rubinfeld [2009]).

A fentiek alapján közgazdasági értelemben akkor beszélünk felelösségteljes innovációról, ha várhatóan minden érintett fél számára összességében több hasznot eredményez, mint költséget, miután az innovátor felméri és önkéntesen figyelembe veszi azokat a feleket érintő hasznokat és költségeket, amelyek pénzbeli kompenzációja az innovátorral semmilyen módon nem történik meg. Internalizálás hiányában azonban a profitmotívumot követve egy innovátor vállalat csupán az $f^{*}$-ig terjedő funkciókat fejlesztené ki, az általa elérhető profit itt lenne maximális. Ennél tovább azért nem érdemes mennie, mert számára minden további funkció nagyobb többletköltséget eredményez, mint többletbevételt. Ha tehát egy felelősségteljes innovátortól azt várjuk el, hogy a saját maga számára profitmaximalizáló $f^{*}$ helyett a társadalom számára optimális, de számára alacsonyabb profitot eredményező $f_{s o c}$ mennyiségü funkciót fejlessze ki, akkor a felelősségteljes vállalatok minden egyéb változatlansága mellett kevésbé profitábilisek lesznek, mint nem felelősségteljes versenytársaik. A fenti gondolatmenetből következik az, ami véleményünk szerint a felelösségteljes innováció széles körü vállalati elterjedésének legfontosabb gátja, hogy az innovátorok profitmaximalizálási célja szemben áll a társadalom életminőség-maximalizáló céljával, és a racionális innovátorok internalizálás hiányában nem fogják a felelösségteljes innovációs modellt választani.

\section{A felelősségteljes innováció által kiváltott információs aszimmetria}

Célszerủ átgondolni azt, hogy milyen módon lehetne piaci alapon úgy befolyásolni az innovátor vállalat költségeit és bevételeit, hogy az innovátorok profitmaximalizálási célja ne álljon szemben a társadalom életminőség-maximalizáló céljával. Úgy gondoljuk, hogy a piac értékeli a felelősségteljesen végzett innovációt és a felelösségteljesen innováló vállalatokat, és hajlandó magasabb árral jutalmazni őket. Ha azonban a vállalatoknak a felelösségteljes viselkedése rejtve marad a fogyasztók elött, akkor ez a magasabb fizetési hajlandóság sem realizálódhat.

Ezt a problémát a közgazdaságtan az információs aszimmetria fogalmával írja le (Stigler [1961/1989], Akerlof [1970]), és lehetséges megoldást is kínál a jelzéselmélet (signalling theory) formájában (Spence [2002], Connelly és szerzötársai [2011]). Az információs aszimmetria erőteljesen jelen van a felelősségteljes innovációt magában foglaló eredmények piacán is, és így a kontraszelekció eredményeképpen azok a fogyasztók sem tudják megtéríteni a felelősségteljes innovációra irányuló erőfeszítéseket, akik erre egyébként képesek és hajlandók lennének.

Egy felelősségteljes innovációt végző vállalat magasabb költségszinttel rendelkezik, mint nem felelősségteljes versenytársai, amennyiben képes felmérni és hajlandó figyelembe venni az innovációja által generált jövőbeli pozitív külső hatásokat. Az 1. ábrán látottak alapján ez a vállalat $f^{*}$ helyett $f_{s o c}$ mennyiségü funkciót fejleszt ki, és természetesen 
az ezzel járó magasabb költségeket szeretné a bevételből ellentételezni. Léteznek olyan fogyasztók - nevezzük őket felelősségteljes fogyasztóknak -, akiknek a fizetési hajlandósága magasabb, mert számukra a termék nyilvánvaló használati értékén felül az is értéket jelent, hogy az innováció felelősségteljes módon ment végbe.

Ha mind a termelöi, mind a vásárlói oldalon vannak felelősségteljes szereplők, akkor már legalábbis elvileg lehetséges a felelősségteljes fogyasztókat a nekik megfelelő felelősségteljes innovátorokkal összepárosítani, amely esetben a magasabb fizetési hajlandóság érvényesíthetö (2. ábra).

2. ábra

Heterogén innovátorok és fogyasztók egy innovatív termék piacán

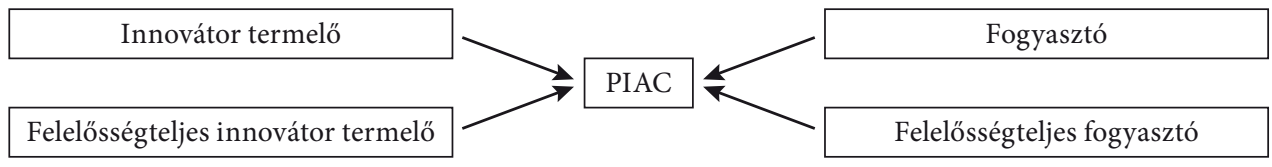

Forrás: saját szerkesztés.

Pusztán a termék alapján azonban a fogyasztók számára nehézséget okozhat megkülönböztetni a felelösségteljes innovátorokat a nem felelősségteljesektől, míg az innovátorok természetesen tudják, hogy ők melyik kategóriába tartoznak, és az áraikat is ennek megfelelően igyekeznek meghatározni. Ez a jól ismert információsaszimmetria-probléma (Akerlof [1970], Spence [1973]), amelyet a vevők számára nem megfigyelhető magasabb minőség okoz, és amely a klasszikus példákban a piac összeomlásához és kontraszelekcióhoz vezet, amikor a „rossz minőségü” termék kihajtja a jó minőségüt a piacról (Gresham-törvény - Rolnick-Weber [1986]). Az információs aszimmetria eredménye a 2. ábrán bemutatott piacon is ugyanaz lenne, mint például Akerlof tragacspiacán: még ha meg is emelkedne az átlagos költségszint (vannak magasabb és alacsonyabb költségủ vállalatok), illetve az átlagos fizetési hajlandóság (a magasabb és az alacsonyabb rezervációs árú fogyasztók miatt), a nem felelősségteljes innovátorok magasabb profitra tennének szert, míg a felelösségteljes innovátorok bevétele nem fedezné a költségeiket, így hosszú távon megváltozna a termelők összetétele, eltolódna a nem felelösségteljes innovátorok felé. A felelősségteljes fogyasztók is - nem tudván megkülönböztetni a kétféle termelőt egymástól - csak a nem felelősségteljes termékért járó árat hajlandók megfizetni, így előáll a kontraszelekció.

Az információs aszimmetriára kínál megoldást a jelzéselmélet (Riley [2001], Spence [2002], Connelly és szerzőtársai [2011]). A nem megfigyelhetően jobb minőségü termékeket gyártó vállalatoknak érdekükben és módjukban áll termékük jobb minőségét jelezni a potenciális fogyasztóik számára, és így magasabb árat érhetnek el. Ha a felelősségteljes innovátorok viselkedése rejtve marad a fogyasztók előtt, akkor kialakul a jelzéselmélet által gyüjtő egyensúlynak (pooling equilibrium) nevezett kimenetel, azaz a szereplők úgy viselkednek, mintha homogén termékek lennének a piacon. Ebben az esetben a felelősségteljes vásárlók magasabb fizetési hajlandósága nem érvényesülhet. Erre a problémára megoldást jelenthet egy olyan jelzés, amelynek segítségével a felelősségteljes innovációt alkalmazó szereplők egyértelmüen és hitelt érdemlően 
képesek a piaci szereplők számára közölni ezen tulajdonságukat. Egy megfelelő jelző használatával létrejöhet a jelzéselmélet által szétválasztó egyensúlynak (separating equilibrium) nevezett egyensúlyi helyzet, amikor is lényegében egy termékdifferenciálás által két részpiac jön létre: az egyik a magasabb minőségü és árú felelősségteljes piac, a másik pedig az alacsonyabb árú és minőségü nem felelősségteljes piac. A hatékony jelző megakadályozza a két piac közötti átjárást. Egy ilyen minőségi jelző segítségével megvalósíthatóvá válik, hogy az innovátor vállalat költségeit és bevételeit piaci alapon lehessen befolyásolni úgy, hogy az innovátorok profitmaximalizálási célja ne álljon szemben a társadalom életminőség-maximalizáló céljával, ezáltal a racionális innovátorok a felelösségteljes innovációs modellt válasszák.

A minősító jelzők egyik leginkább egzakt megjelenési formáját a szabványok jelentik. Terlaak-King [2006] szerint a szabványok lehetővé teszik a vállalatok számára, hogy tanúsítást szerezzenek előre meghatározott követelményeknek való megfelelésükről - jellemzően - második vagy harmadik fél által végzett akkreditáció révén. A szabványok csökkentik a fogyasztók és a vállalatok közötti információs aszimmetriát, lehetővé téve számukra az egyes termékek összehasonlítását. A vállalatok, amelyek bizonyosságot tudnak nyújtani a szabványoknak való megfelelésről, versenyelőnyhöz jutnak minél magasabb a verseny szintje, annál nagyobb az ösztönzés a minősítő jelzőmechanizmusok használatára (Cao-Prakash [2011], Terlaak-King [2006]).

Vannak olyan szabványok, amelyek tanúsítás nélkül, az érintettekkel való közvetlen interakció által alkalmasak a jelzésre. Ilyen az ISO 26000, amely a vállalatok negatív társadalmi és környezeti hatásainak csökkentése szempontjából releváns. A szabványok többsége azonban harmadik fél általi tanúsításhoz kötött. Ha a vállalat megfelel a szabvány által előírt követelményeknek, akkor megfelelőségét harmadik félnél regisztrálhatja (Terlaak-King [2006]). A tanúsítás lényege, hogy a vállalatok hajlandók fizetni és pluszköltségeket vállalni annak érdekében, hogy ezzel jelezzék a fogyasztók számára a szabványnak való megfelelést.

\section{A felelősségteljes innovációt minősítő jelző}

A tanulmányunkban bemutatott összefüggések felvetik, hogy a felelösségteljes innovációval járó pozitív külső hatások internalizálására alkalmas lehet egy szabványtípusú megközelítés. Ennek segítségével a felelősségteljes innováció gyakorlati alkalmazása a gazdasági racionalitás által vezérelve az eddigieknél jóval gyorsabban és jóval szélesebb körben terjedhetne el. A felelösségteljes innovációs szabvány akkor működne hatékonyan, ha megfelelne a következő öt feltételnek.

1. Meg Kell SZÜNTESSE AZ INFORMációs ASZIMMETRIÁt • A felelösségteljes innováció egy lehetséges jelzője lehetővé tenné, hogy a fogyasztók hitelt érdemlően megkülönböztessék egymástól azokat az innovációs termékeket, amelyek felelösségteljes innováció eredményeképpen jöttek létre, azoktól, amelyek nem. A jelző azt a célt szolgálja, hogy két részpiacra (felelősségteljes és nem felelősségteljes piacra) bontsa a piacot (szétválasztó egyensúly), lehetöleg úgy, hogy ne legyen átjárás a piacok között (3. ábra). 
3. ábra

Szétválasztó egyensúly egy innovatív termék piacán

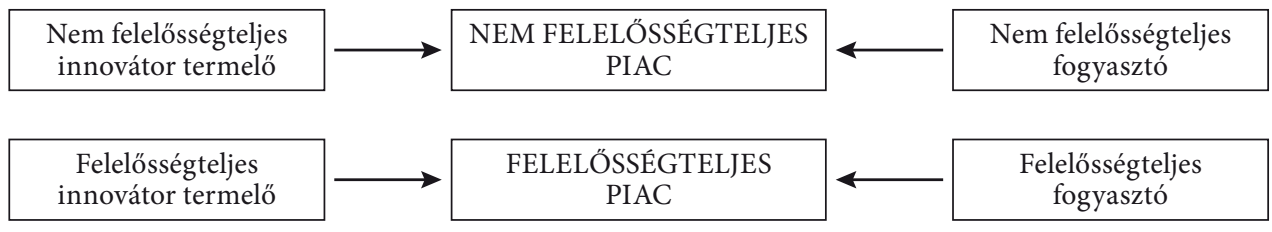

Forrás: saját szerkesztés-

Így a nem felelösségteljes piacon a termék egy alacsonyabb áron, de alacsonyabb minőséggel lenne jelen, nem összetéveszthetö módon a felelösségteljes piacon megjelenö magasabb árú, felelősségteljes innováció eredményeképp előálló termékkel. A piacok átjárásmentes szétválasztása főleg a termelői oldalról lényeges: az kevésbé valószínű ugyanis, legalábbis kevésbé káros, ha egy felelösségteljes fogyasztó lép át az alacsonyabb ár csábítására a nem felelősségteljes piacra. Minél erősebb egy fogyasztó felelősségteljesség iránti preferenciája, annál valószínűbb, hogy a megfelelő információ birtokában a magasabb árú felelősségteljes terméket választja. A nagyobb problémát az okozná, hogyha egy nem felelösségteljes innovátor termelő tudna megjelenni nem felelősségteljes termékével a magasabb árat biztosító felelősségteljes piacon.

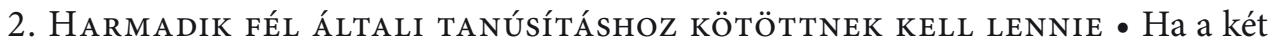
piac szétválasztása nem teljes, például a jelölő minősítés hamisítható vagy alacsony erőfeszítéssel megszerezhető, akkor annak hatása ugyanaz, mint a nem szétválasztott esetben, és ismét kontraszelekciós folyamatok indulnak el. Emiatt fontosnak tartjuk, hogy a felelősségteljes innovációs jelző az ISO-tanúsítványhoz hasonlóan harmadik fél általi akkreditációhoz legyen kötve. Az akkreditáció lényege egyrészt az, hogy vállalatok hajlandók fizetni és többletkötelezettséget vállalni annak érdekében, hogy ezzel jelezzék a fogyasztók számára a többletértéket. Ezenfelül az akkreditáló független harmadik fél jelentősen növeli a jelző hitelességét azzal a piaci gyakorlattal szemben, amikor bizonyos vállalatok magukról állítják, hogy felelősségteljesen végzik innovációs folyamataikat.

3. ÜZLETi TÍPUSÚ INDIKÁTOROK ALKALMAZÁSA • Az akkreditáció kritériumrendszerének pontos megadása túlmutat jelen kutatás keretein, ugyanakkor a lehető legszélesebb nemzetközi tudományos és gyakorlati konszenzuson kell alapulnia. Az eddigi indikátorképzési kísérletek és jelen kutatásunk eredményei alapján azonban megfogalmazhatók az indikátorokkal kapcsolatos követelmények alapelvei. Az eddigi tanulmányok általában a felelősségteljes innováció általános értelemben vett mutatóira összpontosítanak (Eden és szerzötársai [2013], Owen és szerzötársai [2013], Stahl [2013], Yaghmaei [2016]), és jellemzően az Európai Bizottság által megfogalmazott hat kulcselem (társadalom bevonása, nemek közötti esélyegyenlőség, tudományos nevelés, szabad hozzáférés, etika, irányítás) köré rendeződnek (EC [2013]). Ezek azonban nem alkalmasak arra, hogy a felelősségteljes innováció vállalati környezetben történő alkalmazását előmozdítsák. Yaghmaei [2018] kifejezetten üzleti típusú indikátorkészlet létrehozására vállalkozott, és három föcsoportot különböztetett meg (érzékenység, 
megvalósítás, értékelés). Ezeket - precíz operacionalizálást követően - alkalmasnak tartjuk arra, hogy a vállalatok felelősségteljes innovációs akkreditációjának kiindulásául szolgáljanak. A végső kritériumok kidolgozása messzemenően multidiszciplináris feladat, amely felértékeli a közgazdászok iránti igényt a jelenleg többségében nem közgazdászokból álló nemzetközi felelösségteljesinnováció-közösségben.

\section{A FELELŐSSÉGTELJES INNOVÁCIÓ LEGYEN AZ INNOVÁTOR RACIONÁLIS VÁLASZ-} TÁsA • A felelősségteljes innovátorok jelezhetik vevőiknek a felelősségteljes innováció fennállásának tényét, és a felelősségteljes innováció jelző minősítési költségéért cserébe lehetőségük lesz magasabb áron értékesíteni. Az elérhető magasabb ár egyfajta piaci ösztönzővé válik a vállalatok számára, internalizálva a felelősségteljes innovációból származó pozitív externáliákat. A vállalat által választott profitmaximalizáló $f^{*}$ megegyezik a társadalom számára optimális $f_{\text {soc }}$-cal (4. ábra).

\section{4. ábra}

A felelősségteljes innováció minősítő jelző internalizáló hatása
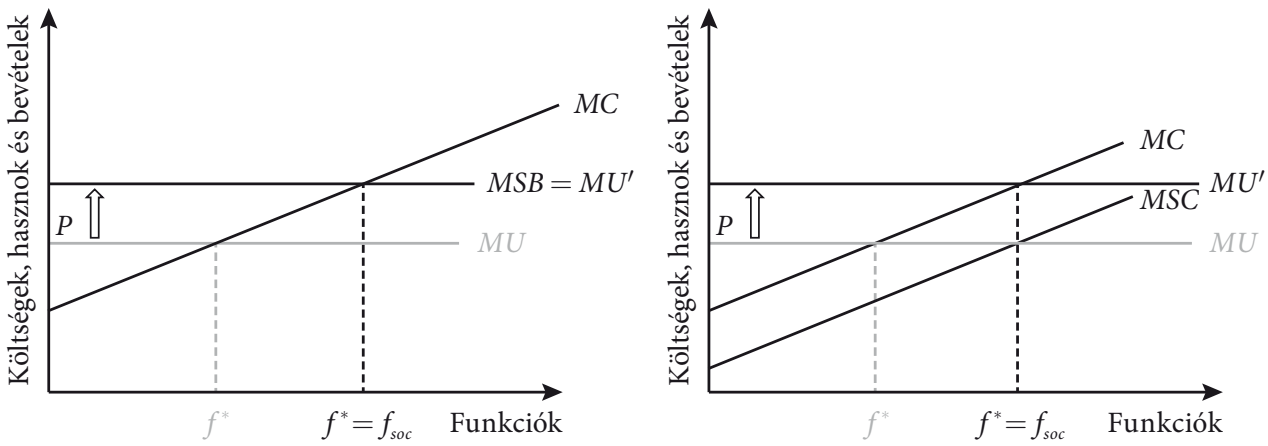

Megjegyzés: a jelöléseket lásd az 1. ábra jegyzetében.

Forrás: saját szerkesztés.

Az internalizáláshoz és a társadalmilag kívánatos eredmény eléréséhez elegendő, hogy a minősitő jelző segítségével a felelősségteljes fogyasztók magasabb fizetési hajlandósága ténylegesen többletbevételt jelentsen a vállalat számára. A felelösségteljes innováció követelményeinek (például több teszt, erősebb minőségbiztosítás stb.) való megfelelést az akkreditációs kritériumok teljesítése állítja elö. A felelősségteljes innovátorok számára ilyen feltételek mellett a felelősségteljes innovációs modell választása racionális.

\section{A FELELŐSSÉGTELJES INNOVÁCiÓ LEGYEN A VÁSÁRLÓ RACIONÁLIS VÁLASZTÁSA •} Abban, hogy a vásárló magasabb árat fizessen egy minősítő jelzővel ellátott termékért, sokféle motiváció vezérelheti. Esetünkben triviálisnak tűnhet, hogy azért választja valaki a felelősségteljes innováció jelzővel ellátott innovációs eredményt, mert ő maga felelösségteljes fogyasztónak tekinti magát, és e preferenciái miatt hajlandó is többet fizetni. Emögött azonban egy racionális döntés is meghúzódik: a felelösségteljes fogyasztó rájön, hogy maga is jövőbeli költségeket spórolhat meg (javíttatás, reklamáció, csere, kárenyhítés, idegeskedés, bizonytalanság stb.) vagy többlethasznot 
élvezhet (jövőbiztosság, kiszámíthatóság, biztonság, nyugalom stb.), ha felelősségteljes terméket vásárol. A minősítő jelző segítségével meg tudja valósítani, hogy az ennek megfelelő magasabb árat valóban csak a felelősségteljes termékekért fizesse meg.

Az ideális eset azlenne, amikor a pozitív externáliák teljes mértékben internalizálhatók lennének, így az innovátor profitmaximalizáló választása az $f_{\text {soc }}$ lenne. Még ha minden többlethaszon vagy elmaradó költség nem is jelenik meg a felelösségteljes fogyasztók által megfizetett magasabb árban (hiszen ezek egy része esetleg nem is ezeknél a fogyasztóknál realizálódik), a legalábbis részleges internalizáció eredményeképpen az innovátorok profitmaximalizálási célja már közelebb áll a társadalom életminőségmaximalizáló céljaihoz.

Mivel a gazdasági önérdek vezeti az innovátorokat a felelősségteljes innováció alkalmazására, ezért ez egy elméleti lehetőség arra, hogy gyorsan és széleskörüen alkalmazzák ezt a szemléletet a racionális innovátorok (1. táblázat). A minősítő jelzőn alapuló módszer esetében a felelősségteljes innováció gyakorlati alkalmazását a gazdasági racionalitás motiválja, ezzel szemben az etikai módszerek esetében a fő motiváció a kutató-fejlesztő egyéni személyes meggyőződése: azaz, hogy megértette, és számára fontos, hogy munkáját abban a szemléletben végezze. Az etikai módszereknél ugyanis cél a kutató-fejlesztő személy gondolkodásának formálása, egyfajta tanulási folyamat lefolytatása. A minősítő jelzőn alapuló módszer esetében a profitcél és a társadalmi cél összehangolása van középpontban, így a kutató-fejlesztő azonosulása a felelősségteljes innovációval nem biztosított. Az etikai módszereknek ugyanakkor egyenes következménye az azonosulás, hiszen belső motivációból indulnak ki. Mindkét esetben szükség van külső szereplöre: az etikai módszereknél a tanulási folyamatot „terelgető” személyre (coach), míg a minősítő jelzőn alapuló módszer esetében a tanúsító bevonása szükséges.

\section{1. táblázat}

Az etikai módszerek és a minősítő jelzőn alapuló módszer összehasonlítása

\begin{tabular}{|c|c|c|}
\hline Megnevezés & Etikai módszerek & $\begin{array}{l}\text { Minősítő jelzőn alapuló } \\
\text { módszer }\end{array}$ \\
\hline Motiváció & $\begin{array}{l}\text { kutató-fejlesztő egyéni } \\
\text { személyes meggyőződése }\end{array}$ & gazdasági racionalitás \\
\hline Cél & $\begin{array}{l}\text { kutató-fejlesztő } \\
\text { gondolkodásának formálása }\end{array}$ & $\begin{array}{l}\text { profitcél és társadalmi cél } \\
\text { összehangolása }\end{array}$ \\
\hline $\begin{array}{l}\text { Kutató-fejlesztő azonosulása } \\
\text { a felelősségteljes innovációval }\end{array}$ & valószínü & bizonytalan \\
\hline $\begin{array}{l}\text { Felelősségteljes innovációs } \\
\text { döntéseket vezérli }\end{array}$ & saját meggyőződés (belső) & piaci előny (külső) \\
\hline Külső szereplö & coach jellegü gondolkodásformáló & akkreditációt végző tanúsító \\
\hline Elméleti terjedési dinamika & lassú & gyors \\
\hline $\begin{array}{l}\text { Alkalmazó innovátorok } \\
\text { elméleti száma }\end{array}$ & viszonylag kevés & viszonylag sok \\
\hline
\end{tabular}

Forrás: saját szerkesztés. 


\section{Összegzés}

Tanulmányunkban arra a kérdésre kerestük a választ, hogy a felelösségteljes innovációra vonatkozó gondolkodást hogyan lehetne széles körben elterjeszteni és vonzóvá tenni az üzleti szféra innovátorai számára is. A témakört egy alternatív gondolatmenettel vizsgáltuk. Kutatásunk során nem a belső motivációs eszközök oldaláról közelítettük meg a kérdést, hanem a külső befolyásoló tényezőket helyeztük előtérbe. A felelősségteljes innováció gyakorlati alkalmazására szolgáló módszerek jelentős része az akadémiai szféra sajátosságaira szabott, az eddig elért eredmények alapján az akadémiai szektorban müködnek hatékonyan. A felelösségteljes innováció széles körben történő terjesztése érdekében azonban fontos, hogy ez a gondolatkör a vállalati szektor körében is ismertté váljon.

Azért, hogy a felelösségteljes innováció minél szélesebb körben beépülhessen a kutató-fejlesztők gondolkodásába és ezáltal a napi munkájukba, az elméleti közgazdaságtani, mikroökonómiai gondolatmenetet hívtuk segítségül. Bemutattuk, hogy a felelősségteljes innovációs modell nemcsak pozitív külső hatásokat generálhat a társadalom számára, hanem ezek az externáliák legalább részben internalizálhatók, ami által az innovátorok számára racionális választássá válhat a társadalmilag kívánatos felelősségteljes innovációs modell alkalmazása. A felelősségteljes innováció széles körü, piaci motivációkon alapuló alkalmazására egy lehetséges módszer a minősítő jelzőkhöz (például ISO) hasonló felelősségteljesinnováció-jelző bevezetése, amelyet a vállalatok költségekre és haszonra való hatása alapján vizsgáltunk.

A tanulmány fö következtetése, hogy egy tanúsítványtípusú megközelítés segítségével a felelősségteljes innováció gyakorlati alkalmazása előmozdítható, és elterjedése a gazdasági racionalitásra alapozva a vállalati szférában is sikeresen megvalósítható. A felelősségteljesinnováció-tanúsítvány alkalmazásával az innovátorok részéről megfigyelhető profitmaximalizálási cél, valamint a társadalom jólét- és életminőség-maximalizálásra való törekvése valószínűleg kevésbé vagy egyáltalán nem ütközik, és ez arra ösztönözheti a racionális innovátorokat, hogy a felelősségteljes innovációs modellt válasszák.

\section{Hivatkozások}

Akerlof, G. [1970]: The Market for ,Lemons': Quality Uncertainty and the Market Mechanism. Quarterly Journal of Economics, Vol. 84. No. 3. 488-500. o. https://doi.org/ $10.2307 / 1879431$.

Bergvall-Kareborn, B.-Hoist, M.-Stahlbrost, A. [2009]: Concept design with a living lab approach. 42nd Hawaii International Conference on System Sciences, IEEE. https:// www.diva-portal.org/smash/get/diva2:1007868/FULLTEXT01.pdf.

Blommestein, H. J. [2006]: Why is ethics not part of modern economics and finance? A historical perspective. Financial Analysts Journal, Vol. 51. No. 1. 7-11. o.

Burget, M.-Bardone, E.-Pedaste, M. [2017]: Definitions and conceptual dimensions of responsible research and innovation: A literature review. Science and Engineering Ethics, Vol. 23. No. 1. 1-19. o. https://doi.org/10.1007/s11948-016-9782-1.

BuzÁs Norbert-Lukovics Miklós [2015]: A felelősségteljes innovációról. Közgazdasági Szemle, 57. évf. 4. sz. 438-456. o. 
CAO, X.-Prakash, A. [2011]: Growing exports by signaling product quality. Trade competition and the cross-national diffusion of ISO 9000 quality standards. Journal of Policy Analysis and Management, Vol. 30. No. 1. 111-135. o. https://doi.org/10.1002/pam.20546.

Connelly, B. L.-Certo, S. T.-Ireland, R. D.-Reutzel, C. R. [2011]: Signaling theory. A review and assessment. Journal of Management, Vol. 37. No. 1. 39-67. o. https://doi. org/10.1177/0149206310388419.

Davis, J. B. [2018]: Ethics and Economics: A Complex Systems Approach. Megjelent: White, $M$. D. (szerk.): Handbook of Ethics and Economics. Oxford University Press, https://papers.ssrn. com/sol3/Delivery.cfm/SSRN_ID3172990_code233483.pdf?abstractid=3172990\&mirid=1.

EC [2013]: Responsible Research and Innovation (RRI), Science and Technology. Special Eurobarometer 401. European Commission, Brüsszel. https://ec.europa.eu/commfrontoffice/ publicopinion/archives/ebs/ebs_401_en.pdf.

Eden, G.-Jirotka, M.-Stahl, B. [2013]: Responsible Research and Innovation: Critical reflection into the potential social consequences of ICT. IEEE 7th International Conference on Research Challenges in Information Science (RCIS).

Felt, U.-Fochler, M.-Sigl, L. [2018]: IMAGINE RRI. A card-based method for reflecting on responsibility in life science research. Journal of Responsible Innovation, Vol. 5. No. 2. 201-224. o. https://doi.org/10.1080/23299460.2018.1457402.

Fisher, E.-Mahajan, R. [2006]: Midstream Modulation of Nanotechnology in an Academic Research Laboratory. Paper presented at the ASME 2006 International Mechanical Engineering Congress and Exposition, november 5-10. 189-195. o. https://doi.org/10.1115/ IMECE2006-14790.

Fisher, E.-Maricle, G. [2015]: Higher-level responsiveness? Socio-technical integration within US and UK nanotechnology research priority setting. Science and Public Policy, Vol. 42. No. 1. 72-85. o. https://doi.org/10.1093/scipol/scu017.

Fisher, E.-RIP, A. [2013]: Responsible innovation: multi-level dynamics and soft intervention practices. Megjelent: Owen, R.-Bessant, J.-Heintz, M. (szerk.): Responsible Innovation: Managing the Responsible Emergence of Science and Innovation in Society. John Wiley \& Sons, 165-183. o. https://doi.org/10.1002/9781118551424.ch9.

Fisher, E.-SchuUrbiers, D. [2013]: Socio-technical integration research: Collaborative inquiry at the midstream of research and development. Megjelent: Doorn, N.-Schuurbiers, D.-van de Poel, I.-Gorman, M. (szerk.): Early engagement and new technologies: Opening up the laboratory. Wiley-Blackwell, New York, 97-110. o.

Fisher, E.-Mahajan, R. L.-Mitcham, C. [2006]: Midstream Modulation of Technology: Governance from Within. Bulletin of Science, Technology and Society, Vol. 26. No. 6. 485-496. o. https://doi.org/10.1177/0270467606295402.

Flipse, S. M.-Van der SAnden, M. C. A.-Osseweijer, P. [2013]: Midstream modulation in biotechnology industry: Redefining what is 'part of the job' of researchers in industry. Science and Engineering Ethics, Vol. 19. No. 3. 1141-1164. o. https://doi.org/10.1007/s11948012-9411-6.

Flipse, S. M.-VAn der Sanden, M. C. A.-Osseweijer, P. [2014]: Improving industrial $\mathrm{R} \& \mathrm{D}$ practices with social and ethical aspects: Aligning key performance indicators with social and ethical aspects in food technology R\&D. Technological Forecasting and Social Change, Vol. 85. 185-197. o. https://doi.org/10.1016/j.techfore.2013.08.009.

Forsberg, E.-M.-Quaglio, G.-O'Kane, H.-Karapiperis, T.-Woensel, L. von-Arnaldi, S. [2015]: Assessment of science and technologies: Advising for and with responsibility. Technology in Society, Vol. 42. 21-27. o. https://doi.org/10.1016/j.techsoc.2014.12.004. 
Grinbaum, A.-Groves, C. [2013]: What Is "Responsible" about Responsible Innovation? Understanding the Ethical Issues. Megjelent: Owen, R.-Bessant, J.-Heintz, M. (szerk.): Responsible Innovation: Managing the Responsible Emergence of Science and Innovation in Society. John Wiley \& Sons, 119-142. o. https:/doi.org/10.1002/9781118551424.ch7.

Harsanyi, J. C. [1977]: Morality and the Theory of Rational Behaviour. Social Research, Vol. 44. No. 4. 623-656. o.

Hausman, D.-McPherson, M.-SAtz, D. [2016]: Economic analysis, moral philosophy, and public policy. Cambridge University Press.

Kargol-Wasiluk, A.-Wildowicz-Giegiel, A.-Zalesko, M. [2018]: The Evolution of the Economic Man. From Homo Oeconomicus to Homo Moralis. Gospodarka Narodowa, The Polish Journal of Economics, Warsaw School of Economics, Vol. 293. No. 1. 33-57. o. https://doi.org/10.33119/gn/100566.

Ko, E.-Kiм, Y. [2020]: Why Do Firms Implement Responsible Innovation? The Case of Emerging Technologies in South Korea. Science and Engineering Ethics, Vol. 26. 2663-2692. o. https://doi.org/10.1007/s11948-020-00224-2.

Lukovics Miklós-Fisher, E.-Udvari BeÁta [2016]: A felelősségteljes innováció iránti fogékonyság fejlesztése a gyakorlatban. Marketing \& Menedzsment, 50. évf. 2. sz. 3-18. o.

Lukovics Miklós-Flipse, S. M.-Udvari BeÁta-Fisher, E. [2017]: Responsible research and innovation in contrasting innovation environments: Socio-Technical Integration Research in Hungary and the Netherlands. Technology in Society, Vol. 51. 172-182. o. https://doi. org/10.1016/j.techsoc.2017.09.003.

Lukovics Miklós-Udvari Beáta-Nádas Nikoletta-Fisher, E. [2019]: Raising Awareness of Researchers-in-the-Making Toward Responsible Research and Innovation. Journal of the Knowledge Economy, Vol. 10. No. 4. 1558-1577. o. https://doi.org/10.1007/s13132019-00624-1.

Nádas Nikoletta-Gonda László-Lukovics Miklós-Udvari Beáta [2017]: Responsible Research and Innovation among SMEs. Icuberd book of papers 2017. University of Pécs. 236-254. o.

Owen, R.-MacNaghten, P.-Stilgoe, J. [2012]: Responsible research and innovation: From science in society to science for society, with society. Science and Public Policy, Vol. 39. No. 6. 751-760. o. https://doi.org/10.1093/scipol/scs093.

Owen, R.-Stilgoe, J.-MacNaghten, P.-Gorman, M.-Fisher, E.-Guston, D. [2013]: A framework for responsible innovation. Megjelent: Owen, R.-Bessant, J.-Heintz, M. (szerk.): Responsible Innovation: Managing the Responsible Emergence of Science and Innovation in Society. John Wiley \& Sons, London, 27-50. o. ttps://doi.org/10.1002/9781118551424.ch2.

PAVie, X.-CARThy, D. [2015]: Leveraging uncertainty: a practical approach to the integration of responsible innovation through design thinking. Procedia-Social and Behavioral Sciences, Vol. 213. 1040-1049. o. https://doi.org/10.1142/8903.

Pavie, X.-Scholten, V.-Cathy, D. [2014]: Responsible Innovation: From concept to practice. World Scientific Publishing, Szingapúr, https://doi.org/10.1142/8903.

Pindyck, R.-Rubinfeld, D. [2009]: Microeconomics. 7. kiadás. Pearson Education, Upper Saddle River, N. J.

Porcari, A.-Borsella, E.-Mantovani, E. [2016]: Responsible-Industry. A Framework for implementing Responsible Research and Innovation in ICT for an ageing society. Rome: Agra. Responsible Industry Project, The European Union's Seventh Framework Programme for Research, Technological Development and Demonstration. http://www. responsible-industry.eu/. 
RILEY, J. G. [2001]: Silver signals: twenty-five years of screening and signaling. Journal of Economic Literature, Vol. 39. 432-479. o. https://doi.org/10.1257/jel.39.2.432.

Rolnick, A. J.-Weber, W. E. [1986]: Gresham's Law or Gresham's Fallacy? Journal of Political Economy, Vol. 94. No. 1. 185-199. o.

Schomberg, R. von [2012]: Prospects for Technology Assessment in a framework of responsible research and innovation. Megjelent: Dusseldorp, M.-Beecroft, $R$. (szerk.): Technikfolgen abschätzen lehren. Bildungspotenziale transdisziplinärer Methoden. Springer, Wiesbaden, 39-62. o.

Schomberg, R. von [2013]: A Vision for Responsible Research and Innovation. Megjelent: Owen, R.-Bessant, J.-Heintz, M. (szerk.): Responsible Innovation: Managing the Responsible Emergence of Science and Innovation in Society. John Wiley \& Sons, London, 51-74. o. https://doi.org/10.1002/9781118551424.ch3.

SchuUrbiers, D. [2011]: What Happens in the Lab: Applying Midstream Modulation to Enhance Critical Reflection in the Laboratory. Science and Engineering Ethics, Vol. 17. No. 4. 769-788. o. https://doi.org/10.1007/s11948-011-9317-8.

Schuurman, D.-De Moor, K.-De Marez, L.-Evens, T. [2011]: A Living Lab research approach for mobile TV. Telematics and Informatics, Vol. 28. No. 4. 271-282. o. https:// doi.org/10.1145/1542084.1542122.

Scotchmer, S. [1991]: Standing on the Shoulders of Giants: Cumulative Research and the Patent Law. Journal of Economic Perspectives, Vol. 5. No. 1. 29-41. o.

SEN, A. [1993]: Does business ethics make economic sense? Megjelent: Minus, P. M. (szerk.): The ethics of business in a global economy. Springer, Dordrecht, 53-66. o.

SPENCE, M. [1973]: Job market signaling. Quaterly Journal of Economics, Vol. 87. No. 3. 355-374. 0 .

SPENCE, M. [2002]: Signaling in retrospect and the informational structure of markets. American Economic Review, Vol. 92. 434-459. o. https://doi.org/10.1257/00028280260136200.

STAHL, B. C. [2013]: Responsible research and innovation: The role of privacy in an emerging framework. Science and Public Policy, Vol. 40. No. 6. 708-716. o. https://doi.org/10.1093/ scipol/sct067.

Stigler, G. J. [1961/1989]: Az információszerzés közgazdaságtana. Megjelent Stigler, G. J.: Piac és állami szabályozás. Közgazdasági és Jogi Könyvkiadó, Budapest, 232-253. o. Angolul: The economics of information. The Journal of Political Economy, Vol. 69. No. 3. 213-225. o. https://doi.org/10.1086/258464.

Stilgoe, J.-Owen, R.-MacNaghten, P. [2013]: Developing a framework for responsible Innovation. Research Policy, Vol. 42. No. 9. 1568-1580. o. https://doi.org/10.1016/j. respol.2013.05.008.

Sutcliffe, H. [2013]: A Report on Responsible Research and Innovation. Matter, London.

TerlaAK, A.-KInG, A. A. [2006]: The effect of certification with the ISO 9000 Quality Management Standard: A signaling approach. Journal of Economic Behavior \& Organization, Vol. 60. No. 4. 579-602. o. https://doi.org/10.1016/j.jebo.2004.09.012.

YAGHMAEI, E. [2016]: Addressing responsible research and innovation to industry. ACM SIGCAS Computers and Society, Vol. 45. No. 3. 294-300. o. https://doi.org/10.1145/ 2874239.2874282.

YAGHMAEI, E. [2018]: Responsible research and innovation key performance indicators in industry. Journal of Information, Communication and Ethics in Society, Vol. 16. No. 2. 214-234. o. https://www.emerald.com/insight/content/doi/10.1108/JICES-11-2017-0066/ full/html. 